\title{
Flexural strength of various kinds of the resin bridges fabricated with 3D printing
}

\author{
Sang-Mo Park1, Seong-Kyun Kim ${ }^{1}$, Ji-Man Park², Jang-Hyun Kim², Yoon-Tae Jeon², Jai-Young Koak ${ }^{1}$ \\ 'Department of Prosthodontics \& Dental Research Institute, Seoul National University, Seoul, Republic of Korea \\ ${ }^{2}$ Department of Prosthodontics, Yonsei University, Seoul, Republic of Korea \\ ${ }^{3}$ Aekyung Chemical Co., Seoul, Republic of Korea
}

Purpose: Manufacturing with AM (Additive manufacturing) technique has many advantages; but, due to insufficient study in the area, it is not being widely used in the general clinic. In this study, differences of flexural strength among various materials of 3 unit fixed dental prosthesis were analyzed. Materials and Methods: A metal jig for specimens that had a 3-unit-fixed dental prosthesis figure were fabricated. The jigs were made appropriately to the specifications of the specimens. Three different kinds of materials of specimens which were NC (mathacrylic esther based), DP-1 (Bisphenol A epoxy acrylate type oligomer based), and DT-1 (urethane acrylate based) were printed with DLP machine. Five specimens for each kind of material were printed with an angle of $30^{\circ}$ from the horizontal surface. The specimens were placed on the jig and the flexural strength was measured and recorded using Universal testing machine. The recorded data was analyzed in SPSS using One-way ANOVA and Tukey HSD to determine the significance of the differences of flexural strength among the groups. Results: The flexural strengths of each group were the followings: NC, $1119 \pm 305$ N; DP-1, $619 \pm 150$ N; DT-1, $413 \pm 65$ N. Using One-way ANOVA and Tukey Honestly Significant Difference test, significant difference was found between NC and the other groups $(P<0.05)$, but there was no significant difference between DP-1 and DT-1 $(P>0.05)$. Conclusion: Higher flexural strength was shown in 3-unit-fixed dental prosthesis that were 3D printed using a DLP machine with NC material. (J Dent Rehabil Appl Sci 2017;33(4):260-8)

Key words: 3D print; flexural strength; digital light-processing printer; 3 unit-fixed dental prosthesis; additive manufacturing

\begin{abstract}
서론
AM (additive manufacturing)을 이용한 치과 보철 물의 제작은 매우 많은 이점이 있다. SM (subtractive manufacturing) 방식으로 보철물을 제작할 경우에는 블 록을 절삭하여 보철물을 제작하기 때문에 부산물들이 발 생하고 그 부산물들을 폐기해야 하므로 재료의 낭비가 심하다. 반면, $\mathrm{AM}$ 방식으로 보철물을 제작할 때에는 필 요한 양 만큼만 보철물 제작에 이용되고 나머지 재료는 그대로 다음 보철물 제작에 활용이 가능하다. 또한 $\mathrm{SM}$

${ }^{*}$ Correspondence to: Seong-Kyun Kim

Professor, Department of Prosthodontics \& Dental Research Institute, Seoul National University Dental Hospital, School of Dentistry, Seoul National University, 103, Daehak-ro, Chongno-gu, Seoul, 30380, Republic of Korea Tel: +82-2-2072-2661, Fax: +82-2-2072-3860, E-mail: ksy0617@snu.ac.kr Received: September 22, 2017/Last Revision: October 3, 2017/Accepted: October 18,2017
\end{abstract}

방식에서는 버의 소모로 인한 비용도 상당한 반면 $\mathrm{AM}$ 방식에는 버 등의 소모가 없어서 버에 대한 비용이 절감 된다. 뿐만 아니라 $\mathrm{SM}$ 방식으로 보철물을 제작할 경우 절삭에 의한 소음이 많이 발생하는 반면 $\mathrm{AM}$ 방식으로 제작할 때에는 절삭과정이 없으므로 $\mathrm{SM}$ 방식에 비하여 소음이 적게 발생한다. ${ }^{1}$ 그리고 기존의 $\mathrm{SM}$ 방식과 마찬 가지로 디지털화가 가능하여 인상 채득 및 다양한 기공 과정의 생략이 가능하므로 시간과 비용을 많이 절약할 수 있게 된다. ${ }^{2}$ 또한 $\mathrm{AM}$ 기술을 사용하면 SM기술보다 정 교한 생산물의 제작이 가능한데 SM의 경우 절삭 기구의

Copyright (C) 2017 The Korean Academy of Stomatognathic Function and Occlusion. (c) It is identical to Creative Commons Non-Commercial License. 
움직임에 제약이 있는 반면 $\mathrm{AM}$ 의 경우에는 그러한 제약 이 없기 때문이다. ${ }^{1} \mathrm{AM}$ 기술로 제작한 레진 보철물이 임 상적으로 용인할 만한 정밀도를 가진다는 연구 결과들도 존재한다. ${ }^{2,3}$ 과거에는 $\mathrm{AM}$ 기기들이 크고 무거웠으나 최 근에는 작고 경량화 된 것도 고무적이다. ${ }^{4}$

이러한 AM기술은 다양한 재료와 기술에 이용될 수 있 다. 폴리머, 세라믹, 금속 등 다양한 재료를 사용하여 보 철물 제작이 가능하다. ${ }^{5} \mathrm{AM}$ 기술로 제작한 임플란트를 식립하고 보철물을 제작한 후 3 년 동안 $94.5 \%$ 의 생존률 을 확인하기도 했고, ${ }^{6}$ 다공성의 Ti-6AL-4V의 표면 거칠 기를 조절하여 조골세포의 생성을 유도하여 임플란트에 $\mathrm{AM}$ 기술 도입이 가능함을 밝혔다. ${ }^{7}$ 치주조직유도재생술 까지도 $\mathrm{AM}$ 기술을 적용할 수 있는 가능성이 제시되었으 며 ${ }^{8}$ 교정장치에 적용해 본 연구, ${ }^{9}$ 국소의치의 조직면을 최 적화하거나, ${ }^{10}$ 클래스프의 물성을 조사하는 데에 ${ }^{11} \mathrm{AM}$ 을 이용한 연구도 있다. 코의 재건, ${ }^{12}$ 눈과 두개골의 재건, ${ }^{13}$ 하악골의 재건, ${ }^{14}$ 광범위한 중안모의 재건 ${ }^{15}$ 등 구강 악안 면 전반의 재건에도 $\mathrm{AM}$ 기술이 적용되었다.

이와 같이 여러 가지 이점이 있고, 다양한 재료에 적용 이 가능한 $\mathrm{AM}$ 기술은 치의학계에서 점차 주목 받고 있 다. 어느 때인가부터 AM기술을 치의학에 적용하기 위해 활발한 연구가 이루어지기 시작하고 있다. 많은 학자들 이 $\mathrm{AM}$ 기술을 치의학에 적용하는 것은 미래의 치의학 발 전에 있어서 필수적이라고 생각하고 있다.

다만, $\mathrm{AM}$ 기술이 치과 임상에 적용되기 위해서는 $\mathrm{AM}$ 기술에 사용하는 재료들의 다양한 성질들에 관한 조사 가 필수적이다. 파절강도, 인장강도, 피로강도 등의 물리 적인 성질, 제작 시 정밀도, 생체 적합성 등등, 다양한 성 질에 관한 연구가 충분히 연구되고 검증되어야 한다.

그러나 치의학 용도로 $\mathrm{AM}$ 을 이용할 때에 사용하는 재료들의 다양한 성질에 관한 연구 결과는 아직 불충분 한 실정이다. 치과용 레진의 물리적 성질에 관한 조사들 이 이루어지고 있으나 아직 그 데이터 양이 충분하지 않
으며 연구 결과들도 한정적이다. 치과용 레진의 경우에, 기존의 조사로는 프린팅 각도에 따른 압축파절강도에 관 한 연구가 있으나, 임상에 사용되는 3 유닛 고정성 보철 형태의 보철물에 관해서는 아직 연구된 결과는 없다.

이 논문에서는 DLP방식으로 출력한 3유닛 고정성 보 철 형태의 보철물에 관하여 굴곡강도를 측정하여 조사하 였다. 이 때에 DLP방식의 프린팅에 사용되는 레진 재료 의 종류에 따라서 그 강도가 어떻게 다른지 조사하였다.

\section{연구 재료 및 방법}

\section{1. 시편 제작}

\section{1) 시편 재료}

실험을 위한 시편 재료로는 DLP 3D 프린트용 레진 을 사용하였다. 레진은 NC (Nextdent Co., Seosterberg, Netherland), DP-1 (Aekyung Chemical Co., Seoul, Korea), DT-1 (Veltz3D Co., Incheon, Korea)의 세 가지 종류를 사용하였다(Table 1).

\section{2) 금속 지그 및 압입자 제작}

금속 지그는 3 유닛 고정성 보철의 임플란트 지대주를 가정한 형태로 제작하였다. 상단으로 갈수록 직경이 작 아지는 원기둥 형태 중 가는 부분은 하악 제 2 소구치 부 분을, 두꺼운 부분은 하악 제 2 대구치 부분을 나타내며 그 사이에는 제 1 대구치에 해당하는 공간은 지대주를 생 략하여 3 유닛 고정성 보철 제작시 폰틱으로 처리할 수 있 게 하였다.

압입자는 하중을 가하는 부분을 $6 \mathrm{~mm}$ 의 구 형태로 제 작하였으며, 기존의 연구를 참조하였다. ${ }^{15}$ 하중을 가하는 방식은 3 유닛 고정성 보철의 굴곡강도를 실험할 때에 사 용하는 다른 연구들에 나타난 방식을 사용하여 고정성 보철의 중심점에 하중을 가하였다(Fig. 1). ${ }^{16-20}$

Table 1. Composition and physical properties of materials

\begin{tabular}{|c|c|c|c|}
\hline & $\mathrm{NC}$ & DP-1 & DT-1 \\
\hline Component & $\begin{array}{l}\text { Monomer based on } \\
\text { methacrylic ester }\end{array}$ & $\begin{array}{l}\text { Bisphenol A epoxy acrylate type oligomer } \\
+2 \text {-functional acryl monomer }\end{array}$ & $\begin{array}{l}\text { urethane acrylate resin, } \\
\qquad \mathrm{SiO}_{2} 800 \mathrm{~nm}\end{array}$ \\
\hline Flexural strength & $\begin{array}{c}\geq 85 \mathrm{Mpa} \\
\text { ISO } 10477: 2003\end{array}$ & $\begin{array}{c}\geq 60 \mathrm{Mpa} \\
\text { KS M ISO } 178 \text { or ASTM790 }\end{array}$ & $\begin{array}{l}\geq 102 \mathrm{MPa} \\
\text { ISO } 4049\end{array}$ \\
\hline Flexural modulus & $\begin{array}{c}\geq 2.1 \mathrm{Gpa} \\
\text { ISO } 10477: 2003\end{array}$ & $\begin{array}{c}\geq 1.8 \text { Gpa } \\
\text { KS M ISO } 178 \text { or ASTM } 790\end{array}$ & $\begin{array}{l}\geq 3.2 \mathrm{Gpa} \\
\text { ISO } 4049\end{array}$ \\
\hline
\end{tabular}




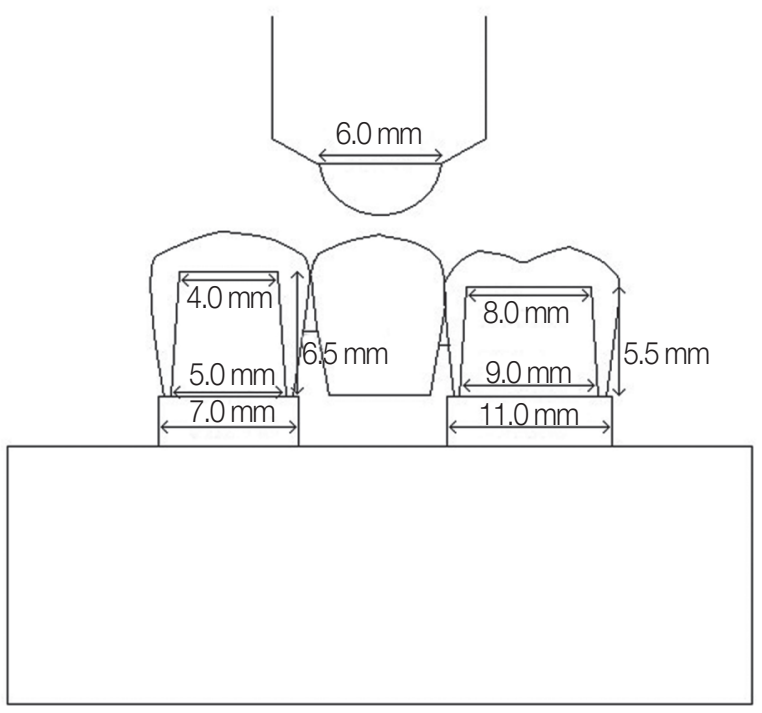

\section{3) 시편제작}

시편은 금속 지그의 크기에 맞추어 제작했다. 우선, 스 캐닝 작업 시 빛의 반사를 막기 위하여 금속 지그에 IPScan-Spray (IP division Co., Hainhausen, Germany) 를 도포하였다(Fig. $2 \mathrm{~A}$ ) 그리고 금속 지그를 $3 \mathrm{D}$ 스캐너 Identica Hybrid (Medit Co., Seoul, Korea)에 넣고 스캐 닝하여 3D 데이터를 얻었다(Fig. 2B). 이렇게 얻어진 가 상의 금속 지그에 $\mathrm{ExoCad}$ 소프트웨어를 이용하여 3유 닛 고정성 보철을 디자인하였다. 그리고 디자인된 고정성 보철에 VeltzBP 소프트웨어를 이용하여 슬라이싱작업을 하고 보철을 DLP 3D 프린터인 DP-150 (Veltz 3D Co.) 로 출력했다(Table 2). 출력 시 사용한 재료는 NC, DP-1, DT-1의 세 가지이다.

Fig. 1. Dimension of metal jig and specimen, indenter.

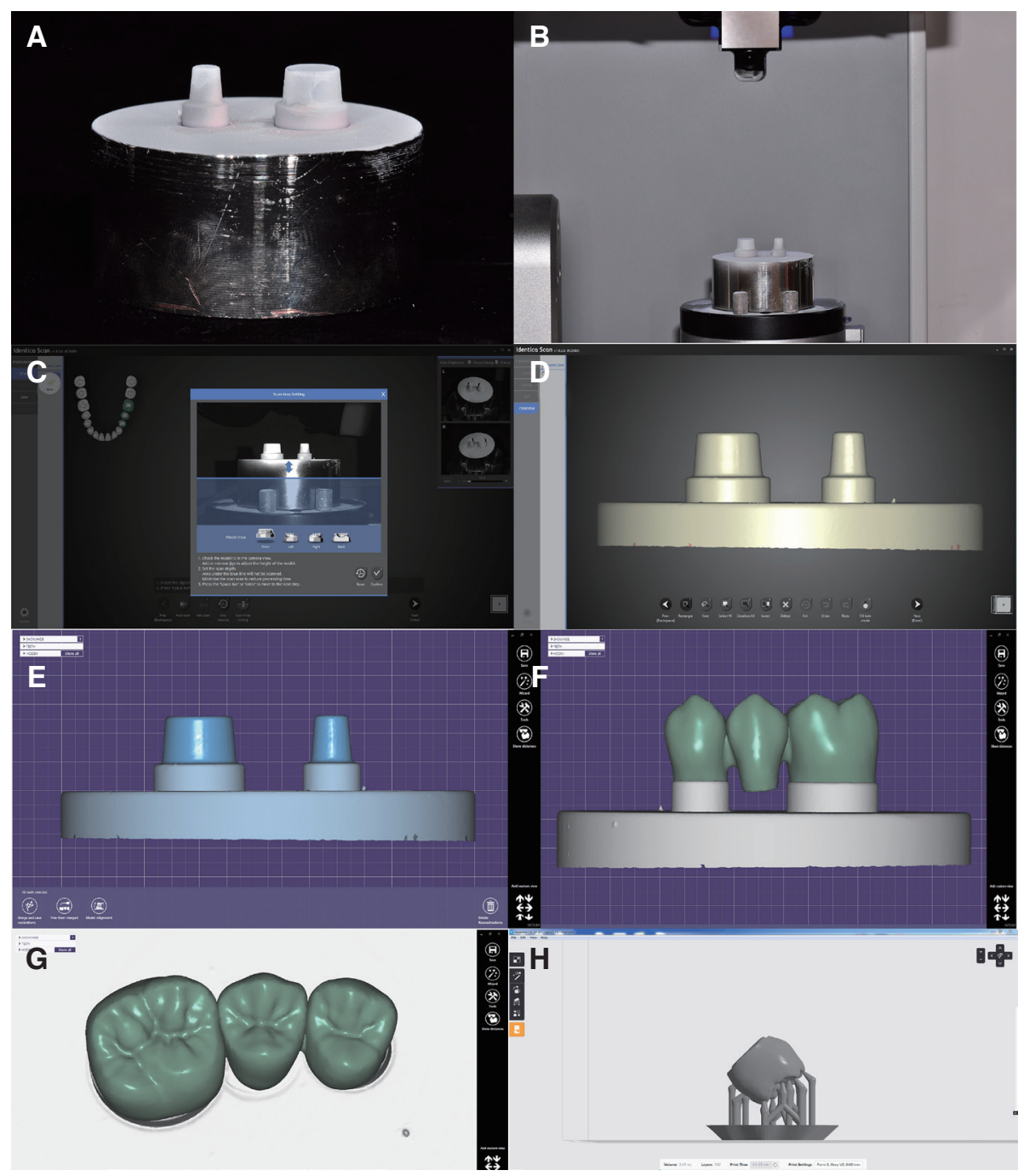

Fig. 2. Procedure of specimen fabrication. (A) Metal jig with IP-scan-spray, (B) Metal jig in the scanner, (C) Scanning area setting, (D) Virtual model of metal jig, (E) Setting cement gap, ( $F, G)$ Bridge design, (H) Specimen designed with supporters. 
Table 2. Specifications of DLP printer

\begin{tabular}{|c|c|c|}
\hline Specification & D1-120 & D1-150 \\
\hline Stacking height & \multicolumn{2}{|c|}{$25-100 \mu \mathrm{m}$} \\
\hline Print dimension & $120(\mathrm{w}) \times 62.5(\mathrm{D}) \times 100(\mathrm{H})[\mathrm{mm}]$ & $150(\mathrm{w}) \times 84.3(\mathrm{D}) \times 100(\mathrm{H})[\mathrm{mm}]$ \\
\hline Speed & \multicolumn{2}{|c|}{$\mathrm{Up}$ to $20 \mathrm{~mm} / \mathrm{hr}$ (vertical direction) } \\
\hline DLP engine & \multicolumn{2}{|c|}{$1920 \times 1080($ Full HD), $405 \mu \mathrm{m}$ UV LED } \\
\hline $\mathrm{XY}$ resolution & $62.5 \mu \mathrm{m}$ & $78 \mu \mathrm{m}$ \\
\hline OS & \multicolumn{2}{|c|}{ LINUX Raspbian Jessie } \\
\hline Power supply & \multicolumn{2}{|c|}{100 - 240 V.ac, $50 / 60 \mathrm{~Hz}$} \\
\hline Power & \multicolumn{2}{|c|}{ Approx $150 \mathrm{~W}$} \\
\hline Weight & \multicolumn{2}{|c|}{ Approx $40 \mathrm{~kg}$} \\
\hline Size & \multicolumn{2}{|c|}{$310(\mathrm{~W}) \times 430(\mathrm{D}) \times 910(\mathrm{H}) \mathrm{mm}$} \\
\hline
\end{tabular}

출력 각도는 수평면에 대하여 $30^{\circ}$ 로 하였다. 또한 각 각의 재료마다 동일한 방식으로 5 개씩의 시편을 제작하 였다. 제작한 시편은 Denstar-300 (Denstar Co., Daegu, Korea)경화기를 이용하여 경화시켰다. 시편의 규격은 Tinschert 등 $^{18}$ 의 연구에서 사용한 규격을 참고하여 연결 부의 두께, 교합면의 교두와, 와, 측면 및 마진의 두께 등 을 결정하였다. 소구치 사이의 연결부는 가로 $4 \mathrm{~mm}$ 에 세 로 $5 \mathrm{~mm}$ 폭으로 하였고, 소구치와 대구치 사이의 연결부 는 가로 $5.5 \mathrm{~mm}$ 세로 $5.5 \mathrm{~mm}$ 의 폭으로 하되 단면은 모 서리가 둥근 역삼각형 형태의 타원으로 하였다.

\section{2. 시험방법}

금속 지그를 만능시험기(Instron8871, Instron Co., Norwood, USA)에 고정시켰다. 금속 지그 위에 시편을 안착시켰다. 시편에 압입자를 이용하여 힘을 가했다. 압 입자의 힘을 가하는 부분은 $6 \mathrm{~mm}$ 직경의 구 형태이다

(Fig. 1).

압입자로 힘을 가할 때 $1.0 \mathrm{~mm} / \mathrm{min}$ 의 속도로 진행하 였으며 파절 전에 가해진 힘의 최고점을 기록하였다(Fig. 3).

이후, 시편에 파절이나 크랙이 발생한 양상을 관찰하 였다. 파절이나 크랙이 주로 발생한 위치, 크기 등을 시편 군에 따라 비교하였다

굴곡강도 실험 후 통계분석에 SPSS를 사용하였으며 일원배치 분산분석을 하였고 사후분석으로는 Tukey를 사용하였다. 독립변수는 시편의 종류이며 종속변수는 시 편의 굴곡강도이다. 통계적 유의수준 $P<0.05$ 로 검증하 였다.

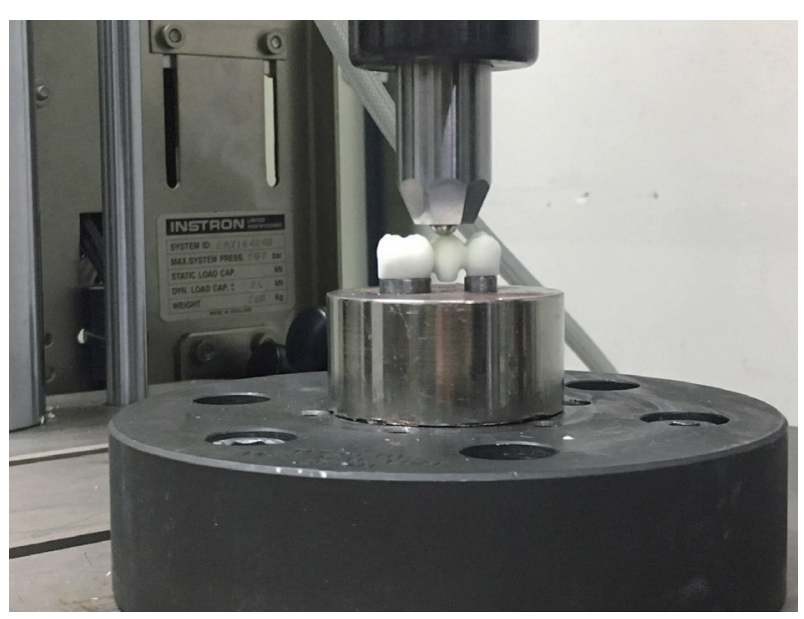

Fig. 3. Flexural strength test of specimen with Universal testing machine.

\section{결과}

\section{1. 굴곡강도}

실험군 NC군의 굴곡강도는 $1119 \pm 305 \mathrm{~N}$, 실험군 DP-1군의 굴곡강도는 $619 \pm 150 \mathrm{~N}$, 실험군 DT-1군의 굴곡강도는 $413 \pm 65 \mathrm{~N}$ 으로 나타났다. 세 군의 시편을 통계적으로 분석했을 때 평균 굴곡강도는 NC > DP-1 $>$ DT-1으로 나타났지만 일원배치분산분석 및 사후검정 (Tukey HSD)적용 및 $P<0.05$ 에서 유의성을 나타낸다 고 보았을 때, $\mathrm{NC}$ 와 다른 군들 사이에만 유의한 차이가 있고, DP-1과 DT-1사이에는 차이가 없는 것으로 나타났 다(Table 3). 
Table 3. Result of statistical analysis

\begin{tabular}{cccccccr}
\hline \multirow{2}{*}{ (I) Specimen } & $\begin{array}{c}\text { Average } \\
\text { flexural } \\
\text { strength }\end{array}$ & (J)Specimen & $\begin{array}{c}\text { Average difference } \\
(\mathrm{I}-\mathrm{J})\end{array}$ & $\begin{array}{c}\text { Standard } \\
\text { error }\end{array}$ & $\begin{array}{c}\text { Significance } \\
\text { Probability }\end{array}$ & \multicolumn{2}{c}{$\begin{array}{c}\text { 95\% Confidence interval } \\
\text { Lowest value }\end{array}$} \\
\hline \multirow{2}{*}{ NC } & \multirow{2}{*}{1119} & DP-1 & $500.20000^{*}$ & 131.24932 & .007 & 145.7144 & 854.6856 \\
& & DT-1 & $706.45000^{*}$ & 139.21092 & .001 & 330.4612 & 1082.4388 \\
\multirow{2}{*}{ DP-1 } & \multirow{2}{*}{619} & NC & $-500.20000^{*}$ & 131.24932 & .007 & -854.6856 & -145.7144 \\
& & DT-1 & 206.25000 & 139.21092 & .336 & -169.7388 & 582.2388 \\
\multirow{2}{*}{ DT-1 } & \multirow{2}{*}{413} & NC & $-706.45000^{*}$ & 139.21092 & .001 & -1082.4388 & -330.4612 \\
& & DP-1 & -206.25000 & 139.21092 & .336 & -582.2388 & 169.7388 \\
\hline
\end{tabular}

(I) and (J) mean specimen groups to compare with. Average difference between (I) and (J) is (I - J).

*Significant difference or $P<0.05$. Unit of date is $\mathrm{N}$. Used One-way ANOVA and Tukey HSD.

\section{2. 시편 파절 양상}

시편은 주로 연결부나 폰틱에서 파절이 일어났음을 보 여주었다. NC재료로 제작한 시편의 경우에는 다수의 조 각으로 파절되어 나뉘어지는 양상이 많이 나타났다. 반 면, DT-1은 모두 완전히 파절되기보다는 결합이 완전히 해체되지 않은 크랙 상태의 파절을 나타내었다. DP-1시 편은 $\mathrm{NC}$ 시편과 DT-1의 중간 정도의 파절상태를 보였 는데 결합이 완전히 해체된 경우도 있었고 결합이 완전 히 해체되지 않은 크랙상태도 있었다. 그러나 모든 실험 군에서 파절은 주로 연결부나 폰틱 부위에서 일어났다 (Fig. 4).

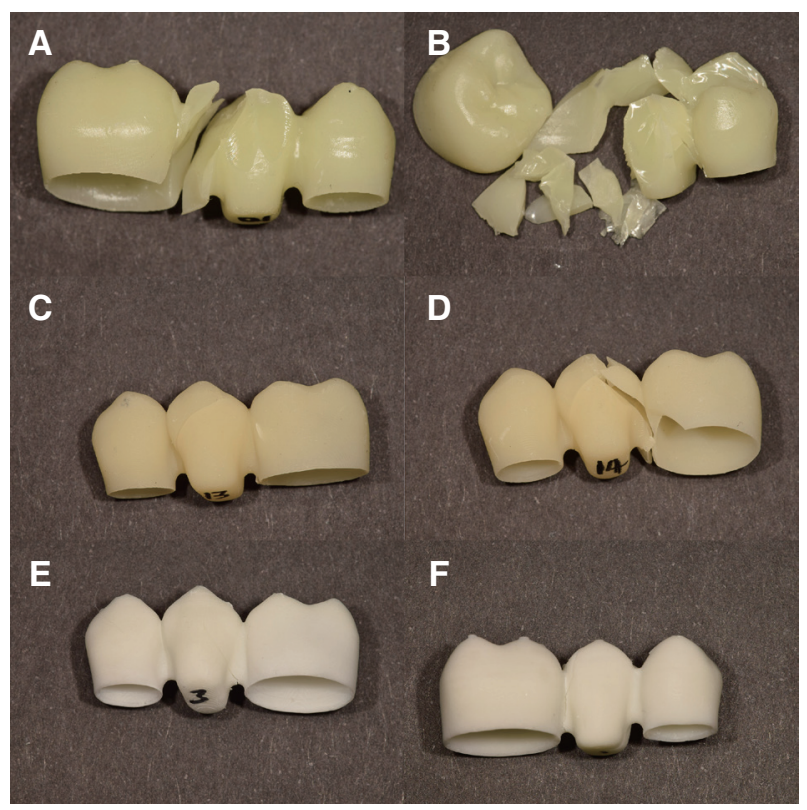

Fig. 4. (A, B) Examples of NC specimen fracture, (C, D) Examples of DP-1 specimen fracture, (E, F) Examples of DT-1 specimen fracture.

\section{고찰}

Alharbi 등 ${ }^{21}$ 은 AM기술을 이용하여 시편을 출력하고 압축파절강도를 측정할 때에 출력 각도가 압축력에 대 해 수직일 때에 압축파절강도가 높게 나타남을 보였으며 이는 출력 시 층간의 결합력이 층 내의 결합력보다 약하 기 때문이라 하였다. 이것을 본 연구에 적용하여 최고의 값을 얻으려 한다면 수평면에 대하여 $0^{\circ}$ 각도로 출력해야 함을 의미한다. 하지만 본 연구에서 출력 각도를 $0^{\circ}$ 로 할 경우에는, 크라운의 내면에 서포터가 자리잡게 되어 내면 상태 또는 시편이 지그에 안착되는 것에 있어서 오차를 야기하게 된다. 따라서 본 실험에서는 편의적인 면을 고 려하여 $0^{\circ}$ 각도가 아닌 $30^{\circ}$ 각도로 시편을 출력하였다.

굴곡강도와 굴곡탄성은 다음과 같이 표현할 수 있다. ${ }^{22}$

$$
\begin{aligned}
& \text { Flexural strength }(\mathrm{MPa})=3 \mathrm{FL} /\left(2 \mathrm{bd}^{2}\right) \\
& \text { Flexural modulus }(\mathrm{GPa})=\left[\left(\mathrm{L}^{3} m\right) /\left(4 b d^{3}\right)\right] / 1000
\end{aligned}
$$

위의 식에 의하면 시편의 규격이 일정할 때에 굴곡강 도는 오로지 힘에 비례한다. 그러나 각 시편 재료를 제공 한 회사들에서 제시한 굴곡강도는 DT-1 > NC > DP-1 이고, 본 연구에서 나타난 굴곡강도는 NC > DP-1 > DT-1로 일치하지 않는다. 이로서, ISO규격이 아닌 임상 에서 사용하는 형태에서는 다른 여러 가지 요소가 굴곡 강도에 개입될 가능성을 보여준다. 임상적으로 사용하는 형태에서는 균일하지 않은 모양이나 형태로 인하여 크랙 의 전파 등이 ISO규격의 시편과는 다른 방식으로 일어날 수 있음을 보여준다.

굴곡탄성률 또한 굴곡 강도와 연관관계를 찾을 수 없 다. 굴곡탄성률은 DT-1 > DP-1 > NC 순서이므로 본 
연구에서 나타난 굴곡강도의 순서 NC > DP-1 > DT-1 와 일치하지 않는다. 그러나 파절 경향성과 연관관계를 좀 더 조사해볼 필요가 있다. 본 연구에서 파절편이 나뉘 어지는 경향은 NC > DP-1 > DT-1 순서로 나타났는데, 굴곡탄성률과 반대의 경향을 나타낸다. 굴곡 탄성률과 파절편이 나뉘어지는 경향 사이에 어떠한 연관성이 있는 지에 대해서는 새로운 연구주제가 될 수 있어 보인다.

시편의 파절이 주로 연결부 및 폰틱부위에서 일어나는 것은 고정성 보철 형태의 보철에 대하여 굴곡강도 실험 을 했던 다른 연구 결과들과도 일치한다. ${ }^{16,17,19,23}$ 따라서 고정성 보철 형태에 있어서 연결부의 강한 형태를 부여하 는 것이 파절에 의한 실패를 줄이는 한 가지 요인이라고 생각할 수 있다.

시편이 파절되는 형태 또한 임상에 있어서 중요한 요소 이다. NC 시편의 경우에는 본 연구에서 굴곡강도 측정 시 가장 우수한 결과를 보여주었지만 파절 시 여러 개의 날카로운 조각들로 나뉘어진다. 실제 임상에 적용했을 때 파절이 일어난다면 파절편에 의해서 환자가 상해를 입을 수도 있다는 점을 생각해야 한다. 파절시에도 결합 이 완전히 해체되지 않고 크랙이 일부분 생기면서 다른 일부분은 결합된 상태로 남아 있다면 날카로운 파절편이 발생하지 않아 임상 적용시에 환자가 상해를 입을 가능 성이 줄어든다. 이러한 점을 고려할 때에는, 비록 본 연구 에서 파절 강도가 가장 낮게 측정되었지만, DT-1재료가 가장 우수하다고 볼 수 있다.

치과용 보철물을 $3 \mathrm{D}$ 프린팅 방식으로 출력할 때에 출 력 각도는 보철물의 정밀도에도 영향을 미친다. 우선, Osman 등 ${ }^{24}$ 은 DLP 방식으로 치과 보철물을 출력할 때 에 가장 정밀한 수복물을 얻을 수 있는 각도는 $135^{\circ}$ 임을 그의 연구에서 밝혔으며, Alharbi 등 ${ }^{25}$ 은 SLA 프린팅 방 식으로 치과 보철물을 출력할 $120^{\circ}$ 를 가장 정밀한 결과 를 얻는 각도라고 언급하였다. 그리고 서포터가 보철물 의 어느 부분에 위치하는가에 따라서 보철물의 정밀도에 영향을 미칠 수 있다. 특히 특정 각도로 출력 시에 크라 운 내면에 서포터가 형성된다면 서포터를 제거한 후 남 은 돌기들을 제거할 때에 내면을 별도로 조정해야만 하 게 되고 그렇게 되면 수복물의 정밀도에 상당한 영향을 미칠 수 있다. 결국 치과 보철물을 $3 \mathrm{D}$ 제작하는 데에 있 어서 출력 각도를 정할 때에는 강도만을 고려할 수 없고, 서포터 형성 위치를 포함한 정밀도 또한 고려 대상이 되 어야 한다.

본 연구에서는 세 가지 재료들 중에서 $\mathrm{NC}$ 가 가장 좋
은 결과를 나타내고 DP-1과 DT-1사이에는 유의한 차이 가 없었지만, DP-1과 DT-1의 제조 방식이 다르기 때문 에 비교에 있어서도 추후에 더 많은 수의 시편으로 연구 하여 유의한 차이가 있는지 조사할 필요가 있다.

또한 프린팅 방식에 있어서, 레진의 경우만 해도, DLP 방식 외에 SLA, FDM 등 여러 가지 방식이 있다. 각각의 방식에 따라서도 시편의 굴곡강도가 어떻게 다른지도 앞 으로 연구해야 할 대상이다.

이 뿐만이 아니다. 재료는 레진 외에도 금속이나 도재, 지르코니아 등 또한 $3 \mathrm{D}$ 프린팅이 가능하면서 치과 보철 물로 사용이 가능하다. 특히 레진을 제외한 다른 종류의 재료에 대해서는 치과 보철학 차원에서의 물성 연구가 매우 부족한 실정이다. 레진 외의 재료의 물성을 조사하 는 것도 치의학에 $\mathrm{AM}$ 기술을 도입하는 데에 있어서 앞으 로 꼭 이루어져야 할 연구이다.

치의학에 적용이 가능한 $\mathrm{AM}$ 재료들의 연구에 있어서 물성 외에도 다양한 연구가 추가적으로 이루어져야 한 다. 물 흡착도, 물에 대한 용해도, 세포독성 등등 많은 연 구가 이루어져야만 한다.

\section{결론}

본 논문에서는 세 종류의 재료를 사용하여 DLP방식 으로 3 유닛 고정성 보철 형태의 시편을 프린팅하였다. 이 렇게 세 군으로 분류한 시편에 대하여 각각 굴곡강도 테 스트를 하여 결과를 얻은 후 비교하였다. 그리하여 다음 과 같은 결론을 얻었다.

굴곡강도는 NC > DP-1 > DT-1으로 나타났으며 사 후검정(Tukey HSD)에서는 NC와 다른 군들 사이에 유 의한 차이가 있고, DP-1과 DT-1사이에는 차이가 없는 것으로 나타났다.

파절양상 관찰 시 $\mathrm{NC}$ 군은 연결부 및 폰틱, 지대치의 크라운 부분 등 여러 부위에서 다수의 파절편이 생성되 었지만 DP-1과 DT-1의 경우에는 대체로 연결부나 폰틱 에서 완전히 파절되지 않고 크랙만 생성되는 양상을 보 였다.

\section{Acknowledgements}

본 논문은 $\mathrm{SNUDH}$ 연구 기금으로 지원으로 연구되었 음(04-2016-0088). 


\section{References}

1. Ishida Y, Miyasaka T. Dimensional accuracy of dental casting patterns created by $3 \mathrm{D}$ printers. Dent Mater J 2016;35:250-6.

2. Kim DY, Jeon JH, Kim JH, Kim HY, Kim WC. Reproducibility of different arrangement of resin copings by dental microstereolithography: evaluating the marginal discrepancy of resin copings. J Prosthet Dent 2017;117:260-5.

3. Park JY, Jeong ID, Lee JJ, Bae SY, Kim JH, Kim WC. In vitro assessment of the marginal and internal fits of interim implant restorations fabricated with different methods. J Prosthet Dent 2016;116: $536-42$.

4. Gebhardt A, Schmidt FM, Hötter JS, Sokalla W, Sokalla P. Additive manufacturing by selective laser melting the realizer desktop machine and its application for the dental industry. Phys Procedia 2010; 5:543-9.

5. Barazanchi A, Li KC, Al Amleh B, Lyons K, Waddell JN. Additive technology: update on current materials and applications in dentistry. J Prosthodont 2017;26:156-63.

6. Tunchel S, Blay A, Kolerman R, Mijiritsky E, Shibli JA. 3D printing/additive manufacturing single titanium dental implants: a prospective multicenter study with 3 years of follow-up. Int J Dent 2016; 2016:8590971.

7. Cheng A, Humayun A, Cohen DJ, Boyan BD, Schwartz Z. Additively manufactured 3D porous Ti-6Al-4V constructs mimic trabecular bone structure and regulate osteoblast proliferation, differentiation and local factor production in a porosity and surface roughness dependent manner. Biofabrication 2014;6:045007. doi:10.1088/1758-5082/6/4/ 045007.

8. Carter SD, Costa PF, Vaquette C, Ivanovski S, Hutmacher DW, Malda J. Additive biomanufacturing: an advanced approach for periodontal tissue regeneration. Ann Biomed Eng 2017;45:12-22.

9. Al Mortadi N, Jones Q, Eggbeer D, Lewis J. Williams RJ. Fabrication of a resin appliance with alloy components using digital technology without an analog impression. Am J Orthod Dentofacial Or- thop 2015;148:862-7.

10. Chen J, Ahmad R, Suenaga H, Li W, Sasaki K, Swain M, Li Q. Shape optimization for additive manufacturing of removable partial dentures - a new paradigm for prosthetic CAD/CAM. PloS One 2015;10:e132552.

11. Nakata T, Shimpo H, Ohkubo C. Clasp fabrication using one-process molding by repeated laser sintering and high-speed milling. J Prosthodont Res 2017;61:276-82.

12. Neto R, Costa-Ferreira A, Leal N, Machado M, Reis A. An engineering-based approach for design and fabrication of a customized nasal prosthesis. Prosthet Orthot Int 2015;39:422-8.

13. Shankaran G, Deogade SC, Dhirawani R. Fabrication of a cranial prosthesis combined with an ocular prosthesis using rapid prototyping: a case report. J Dent (Tehran) 2016;13:68-72.

14. Tsai MJ, Wu CT. Study of mandible reconstruction using a fibula flap with application of additive manufacturing technology. Biomed Eng Online 2014; 13:57.

15. Fernandes N, van den Heever J, Hoogendijk C, Botha S, Booysen G, Els J. Reconstruction of an extensive midfacial defect using additive manufacturing techniques. J Prosthodont 2016;25:589-94.

16. Naveen KS, Singh JP, Viswambaran M, Dhiman RK. Evaluation of flexural strength of resin interim restorations impregnated with various types of silane treated and untreated glass fibres. Med J Armed Forces India 2015;71:293-8.

17. Partiyan A, Osman E, Rayyan MM, Aboushelib M, Ibrahim A, Jimbo R. Fracture resistance of threeunit zirconia fixed partial denture with modified framework. Odontology 2017;105:62-7.

18. Tinschert J, Natt G, Mautsch W, Augthun M, Spiekermann H. Fracture resistance of lithium disilicate-, alumina-, and zirconia-based threeunit fixed partial dentures: a laboratory study. Int J Prosthodont 2001;14:231-8.

19. Rismanchian M, Shafiei S, Nourbakhshian F, Davoudi A. Flexural strengths of implant-supported zirconia based bridges in posterior regions. J Adv Prosthodont 2014;6:346-50.

20. Cardelli PL, Vertucci V, Balestra F, Montani M, Ar- 
curi C. Mechanical evaluation and fem analysis of stress in fixed partial dentures zirconium-ceramic. Oral Implantol 2014:6:55-62.

21. Alharbi N, Osman R, Wismeijer D. Effects of build direction on the mechanical properties of $3 \mathrm{D}$ printed complete coverage interim dental restorations. J Prosthet Dent 2016;115:760-7.

22. Abdulmohsen B, Parker S, Braden M, Patel MP. A study to investigate and compare the physicomechanical properties of experimental and commercial temporary crown and bridge materials. Dent Mater 2016;32:200-10.

23. Dittmer MP, Kohorst P, Borchers L, Stiesch-Scholz
M. Finite element analysis of a four-unit all-ceramic fixed partial denture. Acta Biomater 2009;5:134955.

24. Osman RB, Alharbi N, Wismeijer D. Build angle: does it influence the accuracy of 3D-printed dental restorations using digital light-processing technology? Int J Prosthodont 2017;30:182-8.

25. Alharbi N, Osman RB, Wismeijer D. Factors influencing the dimensional accuracy of 3D-printed full-coverage dental restorations using stereolithography technology. Int J Prosthodont 2016;29:50310. 


\section{D 프린팅으로 제작된 여러 종류의 레진브릿지의 굴곡강도에 대한 연구}

\section{박상모 ${ }^{1}$, 김성균 ${ }^{1 *}$, 박지만 ${ }^{2}$, 김장현 ${ }^{2}$, 전윤태 ${ }^{3}$, 곽재영}

${ }^{1}$ 서울대학교 치과보철학과 치과보철학 및 치의학연구실

${ }^{2}$ 연세대학교 치과보철학과

${ }^{3}$ 애경화학(주)

목적: 치과 보철물을 적층 가공 기술로 제작하는 것은 많은 이점이 있으나 아직까지 연구 결과 부족으로 인하여 임상에 서 널리 적용되고 있지 못하는 실정이다. 이 연구에서는 디지털 광학 기술 방식의 적층 가공 기술을 이용하여 제작한 치 과 보철물에 있어서 재료에 따라 굴곡강도에 유의한 차이가 있는지 연구하기로 한다. 연구 재료 및 방법: 3 유닛 고정성 보철 형태의 시편 제작을 위한 금속 지그를 제작하였다. 지그에 맞게 시편을 디자인하였다. 디자인 한 시편에 대하여 $\mathrm{NC}$, DP-1, DT-1의 세 가지 재료로 디지털 광학 기술 방식의 출력을 하였다. 각 재료마다 5개의 시편을 제작하되 출력 각도를 수평면에 $30^{\circ}$ 로 하였다. 시편을 지그 위에 안착시키고 만능시험기로 굴곡강도를 측정하고 기록하였다. 기록한 데이터는 SPSS 상에서 일원배치분산분석법을 통하여 재료에 따른 파절 강도 차이의 유의성을 조사하였다. 사후 검정(Tukey Honestly Significant Difference test)은 그룹 간의 통계적 차이를 비교하여 시행되었으며 통계적 유의수준은 0.05로 하였다. 결과: 각 군들의 굴곡강도는 NC군은 $1119 \pm 305 \mathrm{~N}$ 로 나타났고 DP-1군은 $619 \pm 150 \mathrm{~N}, \mathrm{DT}-1$ 군은 $413 \pm 65 \mathrm{~N}$ 로 측정 되었다. SPSS를 사용한 일원배치분산분석법 및 Tukey HSD에서는 NC와 DP-1, NC와 DT-1사이에 유의한 차이를 보였 으며 $(P<0.05), \mathrm{DP}-1$ 과 DT-1사이에는 유의한 차이를 보이지 않았다 $(P>0.05)$. 결론: 디지털 광학 기술 방식으로 $3 \mathrm{D}$ 프 린팅을 하여 제작한 3 유닛 고정성 보철 형태의 레진 보철물에 있어서 메타크릴산 에스텔 재료가 높은 굴곡강도를 보여주 었다.

(구강회복응용과학지 2017;33(4):260-8)

주요어: 3D 프린트; 굴곡강도; 디지털 라이트 프로세싱 프린터; 3유닛 고정성 보철; 적층가공

*교신저자: 김성균

(03080)서울특별시 종로구 대학로 103 서울대학교 치과대학 치과병원

Tel: 02-2072-2661 | Fax: 02-2072-3860 | E-mail: ksy0617@snu. ac. kr

접수일: 2017년 9월 22일 | 수정일: 2017년 10월 3일 | 채택일: 2017년 10월 18일 